DOI: http://doi.org/10.21698/simi.2018.fp33

\title{
PROTECTING SURFACE WATER RESOURCES THROUGH SILVICULTURAL METHODS
}

\author{
$\underline{\text { Cristinel Constandache }^{1} \text {, Lucian Dinca }}{ }^{1}$, Nicu Constantin Tudose ${ }^{1}$, Casen Panaitescu ${ }^{2}$

\begin{abstract}
${ }^{1}$ National Institute for Research and Development in Forestry (INCDS) “Marin Dracea, 1 Focsani Station, 7 Republicii, cicon66@yahoo.com, 2,3 - Brasov Station, Closca street, dinka.lucian@gmail.com; cntudose@yahoo.com, Romania

${ }^{2}$ Petroleum-Gas University of Ploiesti, 39 Bucuresti blvd., Ploiesti, c.panaitescu@gmail, Romania
\end{abstract}

\begin{abstract}
Water was considered an inexhaustible natural resource until reality has proven its reverse. Climatic changes increase the pressure on surface runoff and groundwater, amplifying regional differences. As such, the necessity to adapt to climatic changes implies applying certain biologic/silvicultural works for protecting water resources. Water is strongly connected with forests so that forests fulfil an exceptional hydrological purpose. In this paper we presents some types of silvotechnical works realized in the past for improving degraded lands from Vrancea area, as well as the results of investigations concerning the efficiency of this kind of works in protecting water resources. The investigations were realized in Caciu-Barsesti torrential watershed, an affluent of Putna River (pilot area in CAMARO-D project) situated in the Curvature Subcarpathians. The investigations have targeted forest ecosystem installed on degraded lands mainly comprised of Scots pine and European black pine, as well as the management/consolidation technologies used for eroded lands and their effects in reducing soil and leakage erosions. Forest ecosystems realized through the afforestation of degraded land have an important role in retaining, filtering water and in regulating the course of surface waters, as well as in reducing soil erosion and transporting alluvium. All these roles have an effect in protecting water resources, in maintaining their quality and ensuring a permanent water flux. Amongst the most important effects exerted by forest plantations from degraded lands we mention: reducing soil erosion, improving pedostational conditions, and regulating surface and depth leakages. In comparison with unafforested lands, degraded afforested lands present surface leakages of 4 up to 10 times lower as well as a much more reduced specific erosion (0.06 t.ha ${ }^{-1}$ year $^{-1}$, in comparison with 50300 t.ha $^{-1}$ year $^{-1}$ ).
\end{abstract}

Keywords: afforestation degraded lands, runoff, soil erosion, water resources 


\section{INTERNATIONAL SYMPOSIUM "THE ENVIRONMENT AND THE INDUSTRY", SIMI 2018, PROCEEDINGS BOOK}

\section{Introduction}

As ecosystems, water and forest are the most important natural resources of the Planet as both provide nutrition, energy and shelter, having multiple functions and services for both the environment and its inhabitants. On short, without water, forests could not exist. On the other hand, through forests, water sources, their distribution and circulation are modified while the quality of water is highly improved. As a result, we can affirm that water and forest interact and are influencing one another in a positive manner (Chang 2006).

Most drinkable water resources from Romania originate in afforested hill and mountain areas. In present times, we must acknowledge that water and forests are not two independent components of our environment as they are linked by a strong bond. Among the most important result of these bond, with a direct impact on socioeconomic objectives, we mention leakage (expressed through its quantum) and alluvium transportation. Forests act as a sponge and filter that retains precipitation water, which it releases gradually, supplying springs. In the absence of forests, water originating from precipitations is instantaneously drainage causing soil erosion, landslides and floods.

As such, in the context of ecosystem degradations (as a consequence of climatic changes and uncontrolled aggressive human interventions), waters can become dangerous if proper management and land repartition measurements are not undertaken. It is a well-known fact that approximately $90 \%$ of natural calamities are caused by climatic phenomenon, especially precipitations. The statistic from the last decade show that the total number of natural calamities, including hydrometeorological ones, have an increased tendency of apparition and intensity.

Proper managed forest ecosystems play an important role in retaining and filtering water, as well as in regulating surface water courses, reducing soil erosion and transporting alluvium. All these aspects have an effect in maintaining water quality and in ensuring a permanent water flux.

Amongst the measures and actions for rehabilitating degraded areas with a role in protecting water resources, for whose achievement the silvicultural sector contributes, we mention anti-erosion management plans and the ecological reconstruction through the afforestation of degraded lands. These are followed simultaneously by increasing the percentage of surfaces covered with forest vegetation in adverse areas and ensuring a minimum afforestation percentage of $30 \%$ in torrential watershed (Constandache et al 2016, Popov et al 2017). For the catchment situated upstream of accumulation lakes, the minimum forest percentage should be of approximately $60 \%$ in mountain areas and $40 \%$ in hill areas (Giurgiu, 2010). It is estimated that from the total lake accumulation capacity of 13 billions square meters, 3.6 billions $\mathrm{cm}$ are cogged (Costin 2006). The significant increase of the afforestation degree of large watersheds represents an important request for preventing and stopping floods, as well as for rehabilitating and maintaining an equilibrated water regime (Clinciu 2008).

The present paper's objective is to identify and analyse the most efficient types of silvotechnical works realized in the past in Vrancea area for improving/ecologically 


\section{INTERNATIONAL SYMPOSIUM "THE ENVIRONMENT AND THE INDUSTRY", SIMI 2018, PROCEEDINGS BOOK}

reconstructing degraded lands that have a hydrological and anti-erosional role, as well as an impact on protecting water resources.

\section{Materials and Methods}

The investigations were realized in reclamation perimeters from Putna-Vrancea watershed, situated in the Curvature Subcarpathian area. This region is one of the areas most affected by land degradation processes as a result of inconsiderate forest exploitations realized at the beginning of the $20^{\text {th }}$ century. The research has targeted forest ecosystems installed on degraded lands, the management/consolidation technologies for eroded or clough lands, as well as their effect in reducing soil erosion and leakage.

Table 1. The main characteristics of drainage parcels from Caciu - Barsesti perimeter, during May-October 2014

\begin{tabular}{|c|c|c|c|c|c|}
\hline $\begin{array}{l}\text { Experi- } \\
\text { mental } \\
\text { plot/ } \\
\mathrm{S}^{*} \\
\left(\mathrm{~m}^{2}\right) \\
\end{array}$ & $\begin{array}{l}\text { Erosion } \\
\text { Degree }\end{array}$ & $\begin{array}{l}\text { Exposi- } \\
\text { tion, } \\
\text { (descent } \\
\text { degrees) }\end{array}$ & $\begin{array}{l}\text { The vegetation's synthetic } \\
\text { characterization }\end{array}$ & $\begin{array}{c}\text { Average } \\
\text { drainage } \\
\text { (\%) }\end{array}$ & $\begin{array}{c}\text { Average } \\
\text { specific } \\
\text { erosion } \\
\text { (t/ha) }\end{array}$ \\
\hline$\frac{1 \mathrm{C}}{142}$ & $\begin{array}{l}\text { Very } \\
\text { strong } \\
\text { towards } \\
\text { excessive }\end{array}$ & $\begin{array}{c}E \\
(38)\end{array}$ & $\begin{array}{l}\text { White sea buckthorn, on } 0.6 \\
\mathrm{~S}^{*} \text { (average height of } 1.9-2.5 \\
\mathrm{~m} \text { ) and dogrose on } 0.3 \mathrm{~S} \\
\text { (average height of } 1.5-2.0 \mathrm{~m} \text { ). }\end{array}$ & 1.7 & 0.06 \\
\hline$\frac{2 \mathrm{C}}{554}$ & $\begin{array}{l}\text { Very } \\
\text { strong }\end{array}$ & $\begin{array}{c}\mathrm{V} \\
(30)\end{array}$ & $\begin{array}{l}\text { Scots pine stand }(80 \%) \text {, black } \\
\text { pine }(20 \%) \text { and disseminated } \\
\text { manna ash, } 39 \text { years old, } 0,8 \\
\text { consistency; white sea } \\
\text { buckthorn on } 0.4 \mathrm{~S} \text {. }\end{array}$ & 0.5 & 0.02 \\
\hline$\frac{3 \mathrm{C}}{318}$ & $\begin{array}{l}\text { Very } \\
\text { strong }\end{array}$ & $\begin{array}{c}\mathrm{V} \\
(20)\end{array}$ & $\begin{array}{l}\text { Black pine stand, } 39 \text { years old, } \\
0.7 \text { consistency; white sea } \\
\text { buckthorn on } 0.1 \mathrm{~S} \text {. }\end{array}$ & 0.6 & 0.03 \\
\hline$\frac{4 \mathrm{C}}{276}$ & $\begin{array}{l}\text { Very } \\
\text { strong }\end{array}$ & $\begin{array}{l}\mathrm{V} \\
(27)\end{array}$ & $\begin{array}{l}\text { Black pine stand, } 37 \text { years old, } \\
0.7 \text { consistency; white sea } \\
\text { buckthorn on } 0.8 \mathrm{~S} \text {. }\end{array}$ & 0.7 & 0.05 \\
\hline$\frac{8 \mathrm{C}}{195}$ & Strong & $\begin{array}{c}E \\
(11)\end{array}$ & $\begin{array}{l}\text { Mixture Scots pine and Black } \\
\text { pine Stand, } 39 \text { years old, } 0.6 \\
\text { consistency. }\end{array}$ & 0.7 & 0.05 \\
\hline$\frac{9 \mathrm{C}}{230}$ & Strong & $\begin{array}{c}E \\
(11)\end{array}$ & $\begin{array}{l}\text { Mixture Scots pine and Black } \\
\text { pine Stand, } 39 \text { years old, } 0.8 \\
\text { consistency. }\end{array}$ & 0.5 & 0.02 \\
\hline
\end{tabular}

S*=surface

The investigations concerning silvotechnical works had as main objective the behaviour and efficiency of works realized for the ecological reconstruction of degraded lands. As such, the research was realized in experimental areas situated on 


\section{INTERNATIONAL SYMPOSIUM "THE ENVIRONMENT AND THE INDUSTRY", SIMI 2018, PROCEEDINGS BOOK}

strongly eroded lands from Caciu-Barsesti torrential hydrographic watershed (tributary stream of Putna river).

Establishing the leakage coefficient (\%) for turbidity (loading with suspension sediments, g/l) and specific erosion (t/ha) was realized through measurements of water volume and alluvium from well demarcated parcels situated in different stand situations installed on strongly and very strongly eroded lands with the age of 37-39 years and a consistency between 0.6 and 0.9 (Table 1). The volume of water charged with sediments was collected in specially located basins at the base of parcels. Water volume was related with the parcel's surface and the volume of precipitations fallen in the analysed period.

The drainage sediments were gathered by filtering samples extracted from basins, dried at $105^{\circ} \mathrm{C}$ and then weighted. The resulted quantity was reported to the parcel's surface, resulting the quantity (or volume) or eroded soil after a rain with certain characteristics from surfaces with different types of forest vegetations. The precipitations were recorded with a pluviography and pluviometer installed near the drainage parcels.

\section{Results and Discussion}

Silvotechnical works realized in the past for improving degraded lands

Amongst the silvotechnical works realized for improving degraded lands in reception basins, the decisive role was played by biological works (afforestation), both in regard to the soil's recovery and conservation, as well as in regulating drainage. These types of works represent an auto regeneration property, as well as the generation of vegetal production. Biological works are also useful in consolidating slopes, springs, banks and riverbeds (Figure 1 and Figure 2). The necessity of afforestation works for degraded lands (eroded, clough, sliding) in regard with hydrotechnical works is a fundamental principle in re-establishing and maintaining an equilibrated water regime (Clinciu 2008).

Special consolidation works are necessary for slopes affected by erosion or clough in order to stabilize sediments sources even at their formation place as well as for ensuring the success of afforestation works (biologic). Examples of these types of slopes are simple terraces, terraces supported by small or intersected fences, terraces supported by benches or "vegetally armed" terraces. 


\section{INTERNATIONAL SYMPOSIUM "THE ENVIRONMENT AND THE INDUSTRY", SIMI 2018, PROCEEDINGS BOOK}

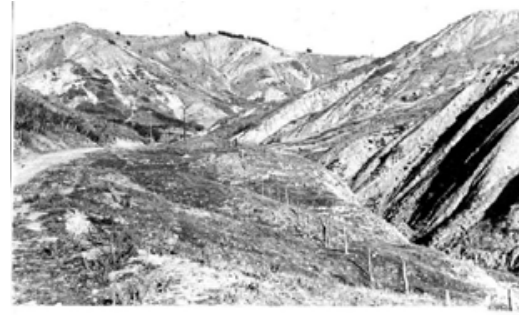

Figure 1. Scaune-Valea Sarii Perimeter before afforestation (photo Costin 1954, INCDS „Marin Dracea” archive)

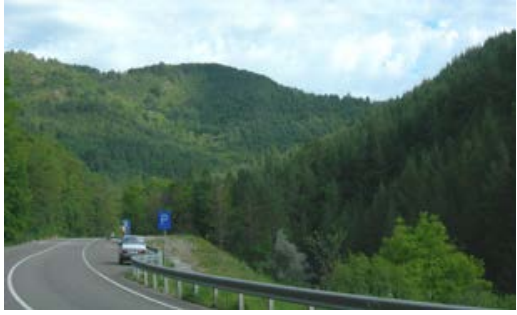

Figure 2. The same perimeter but afforested (photo Constandache 2012, INCDS „Marin Dracea” archive)

The enterprise investigations have shown that the purpose of these works is: to retain precipitation water and upstream eroded materials; to reduce drainage volumes and the water's drainage speed on slopes; to sustain seedlings in the first 23 years from installation.

The research realized 30-50 years after the consolidation works (Constandache \& Nistor 2008, Constandache et al 2010) have shown that the most efficient were:

-terraces supported by benches from strongly eroded lands with stones on slopes that survived even after 40 years; the plantations from terraces supported by benches have led to very good results especially when pine seedlings with protected roots were used, their maintenance rate being of over 90\% (Traci \& Untaru 1986).

-vegetally armed terraces (Figure 3) in most eroded, clough lands and detachment ramps from areas in which white sea buckthorn is naturally installed; the white sea buckthorn stems, branches and roots used for constructing terraces have entered in vegetation in a high percentage (50...70\%), leading to the formation of vegetal belts that play a significant role in dissipating and stopping superficial drainage and in stopping soil erosion; furthermore, this method has led to a considerable cost reduction (with almost 60\%) in comparison with other methods, while the definitive success of the achievement's duration was reduced with at least two years (Traci \& Untaru 1986); in plantations realized on vegetally armed terraces (Figure 4) the growth of planted species (Black pine and/or Scots pine) were also considerably higher in comparison with other types of works (Constandache et al 2016, SilvestruGrigore et al 2018); this fact is explained by the higher capacity of water retention and the soils enrichment with nitrogen resulted from white sea buckthorns (Untaru et al 2013, Dinca et al 2018).

\section{Hydrological and anti-erosion efficiency}

Water drainage causes erosion which causes lands to lose their retention and water storage capacity with $20-90 \%$ (Untaru et al 2006). These lands represent one of the most altered segments of the environment. They are favouring and increasing ecological derangements, being the main focal points for sediments alimentation during surface runoff, considerably affecting the biological and habitat diversity. 


\section{INTERNATIONAL SYMPOSIUM "THE ENVIRONMENT AND THE INDUSTRY", SIMI 2018, PROCEEDINGS BOOK}

The effects of forest vegetations were constantly monitored over time in different situations, emphasizing their hydrological and anti-erosion efficiency.

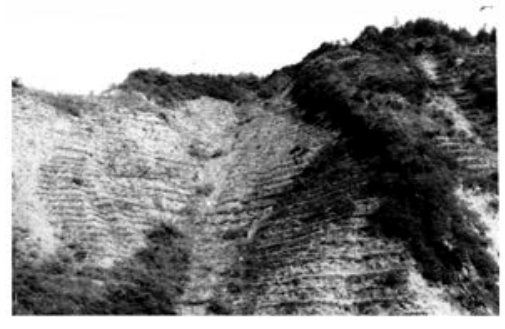

Figure 3. Consolidation of degraded lands with "vegetally armed" terraces (photo Untaru 1979, INCDS „Marin Dracea” archive)

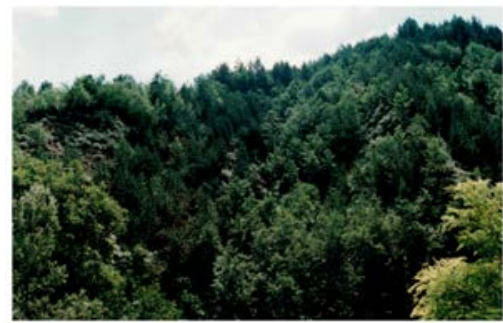

Figure 4. The same terrain after approximately 35 years (photo Constandache 2015, INCDS „Marin Dracea” archive)

The following aspects were obtained based on observations made to the pluviographic network and parcels for studying surface runoff situated in protection forest cultures comprised of Black pine and/or Scots pine mixed with white sea buckthorn, installed on strongly to very strongly eroded/clough lands (Table 2 precipitations recorded and that have caused surface runoff during May-October 2015 in Caciu-Barsesti experimental perimeter):

-22 rains were registered in the analysed period, leading to a cumulation of 471.9 $\mathrm{mm}$; among these, 9 rains have caused surface runoff reaching $453.1 \mathrm{~mm}$; the maximum rain was registered during 01-28 July, having a quantum of $119.9 \mathrm{~mm}$, being also the rain with the maximum intensity $(1.56 \mathrm{~mm} / \mathrm{min})$; May and July are the richest months in rains, especially torrential ones;

-the maximum sediments loading was caused by rains of over $60 \mathrm{~mm}$, on strongly eroded lands with a reduced degree of vegetation cover; the maximum quantity (10 $\mathrm{g} / \mathrm{l}$ ) was registered in parcel 3C during a rain of approximately $111 \mathrm{~mm}$ recorded during the end of May; the average turbidity (loading with suspension sediments) of drainage waters reaches $84 \mathrm{~g} / \mathrm{l}$ in un afforested very strongly towards excessive lands and $7-13 \mathrm{~g} / \mathrm{l}$ in afforested degraded lands; in the mature common beech forest the average turbidity was of 2,6 g/l (Untaru 2000). 


\section{INTERNATIONAL SYMPOSIUM "THE ENVIRONMENT AND THE INDUSTRY", SIMI 2018, PROCEEDINGS BOOK}

Table 2. The synthesis of data concerning precipitations recorded in Caciu-Barsesti hydrographic basin during May-October 2014

\begin{tabular}{cccccc}
\hline \multirow{2}{*}{ No. } & \multirow{2}{*}{ Period/ Day } & $\boldsymbol{\Delta t}$ & $\boldsymbol{\Delta h}$ & I average & I max \\
\cline { 3 - 6 } & & $\mathrm{min}$ & $\mathrm{mm}$ & $\mathrm{mm} / \mathrm{min}$ & $\mathrm{mm} / \mathrm{min}$ \\
\hline 0 & 1 & 2 & 3 & 4 & 5 \\
\hline 1 & 30.05 .2014 & 1880 & 111.1 & 0.059 & 1.46 \\
\hline 2 & $05-06.06 .2014$ & 460 & 9.3 & 0.02 & 0.093 \\
\hline 3 & 16.06 .2014 & 845 & 26.5 & 0.031 & 0.17 \\
\hline 4 & $20-21.06 .2014$ & 305 & 7.9 & 0.026 & 0.08 \\
\hline 5 & 04.07 .2014 & 1645 & $\mathbf{1 1 9 . 9}$ & 0.084 & 1.56 \\
\hline 6 & 20.08 .2014 & 1005 & 79 & 0.079 & 0.66 \\
\hline 7 & 27.09 .2014 & 685 & 29.5 & 0.043 & 0.36 \\
\hline 8 & 17.10 .2014 & 1275 & 27.2 & 0.038 & 0.2 \\
\hline 9 & $19-20.10 .2014$ & 560 & 42.7 & 0.076 & 0.36 \\
\hline \multicolumn{7}{c}{ TOTAL } & $\mathbf{4 5 3 . 1}$ & & \\
\hline
\end{tabular}

Previous results (Untaru et al 2013) have led to the conclusion that rains under 30 $\mathrm{mm}$ with a $50 . .55 \%$ of the total precipitation quantity that have generated drainages generate under $15 \%$ of the erosion's quantum, while the ones larger than $30 \mathrm{~mm}$ generate over $85 \%$ of the quantity of eroded material.

The average surface runoff coefficient is larger in parcel $1 \mathrm{C}(1.7 \%)$. This fact is caused by the lands' high slope and strong towards excessive erosion and its coverage with over $90 \%$ shrubs: white sea buckthorn and dogrose (Table 1). In all the other parcels - 2C, 3C, 4C, 8C and 9C (37-39 year old pine stands) - the average surface runoff coefficient is reduced with up to $35 \%$, being situated in the interval $0.5-0.7 \%$.

As such, the investigations realized on parcels created especially for the study of surface runoff and installed on pine and sea buckthorn cultures (Barsesti perimeter) have proved that the surface runoff is of 4 up to 10 times lower in the degraded pastures.

The average specific erosion (t/ha) was reduced considerably on afforested parcels to under 0.06 t.ha $^{-1}$ year $^{-1}$, in comparison with 50 up to 300 t.ha $^{-1}$ year $^{-1}$ as it was previously eroded before the afforestation works (Untaru 2000) or before excessively eroded lands without forest vegetation. As such, in 2014 the average specific erosion values are situated between 0.02 t.ha $^{-1}$ year $^{-1}$ in parcels $2 \mathrm{C}$ and $9 \mathrm{C}$ and 0.06 t.ha $^{-1}$ year $^{-1}$ in parcel $1 \mathrm{C}$.

The realized investigations have emphasized an increase of protection forest cultures efficiency in regard with their evolution in time and structural diversity. If forest cultures under 20 years old present average surface runoff coefficients between 1 and $3 \%$, after the age of 25 this number is reduced to $0.5-1.8 \%$ and to 0.5 and $0.7 \%$ after the age of 35 . In the same manner, the average specific erosion was reduced in regard with the culture's evolution from $0.4 \ldots 0.7$ t.ha $^{-1}$.year ${ }^{-1}$ after 25 years from the installation of protection forest cultures (Untaru et al 2013), to under 0.06 t.ha $^{-1}$.year

${ }^{1}$ at over 35 years. 


\section{INTERNATIONAL SYMPOSIUM "THE ENVIRONMENT AND THE INDUSTRY", SIMI 2018, PROCEEDINGS BOOK}

As the diversity, number (abundance) of species or the degree of soil coverage with arbustive or wood species is larger, as much the impact of precipitations and the specific erosion decreases. The erosion of superior soil horizons significantly changes water circulation conditions on slopes, reducing the water's infiltration speed and capacity in soil, as well the water availability that leaks on slopes. Furthermore, the soil's resistance towards the impact of rain drops is also reduced.

All these results emphasize the hydrological and anti-erosion efficiency of protection forest cultures as well as of silvotechnical works realized on degraded lands.

\section{Conclusions}

Forest ecosystems realized through the afforestation of degraded lands play an important role in retaining and filtering water, as well as in regulating surface water courses, in reducing soil erosion and transporting sediments. These lands represent one of the most altered segments of the environment: they favour and amplify ecological derangements, being the main focal points of sediments alimentation during torrential rains, considerably affecting the habitats and their biological diversity.

The efficiency of silvicultural methods applied for the afforestation of degraded lands is proven by ensuring installation and development conditions for forest cultures that have a hydrological and anti-erosion protection role. Their effect is manifested in protecting water resources, maintaining their quality and in ensuring a permanent water flux.

The role of silvotechnical works for managing degraded lands is to retain water from precipitation and eroded materials from upstream; to reduce drainage volume and the speed of water drainage on slopes; to sustain seedlings in the first 2-3 years from plantation. On afforested degraded lands surface drainage was 4 to 10 times reduced in comparison with unafforested lands, registering values under 0.5 and $0.7 \%$, while the specific erosion was reduced to under 0.06 t.ha $^{-1}$ year $^{-1}$, in comparison with 50 up to 300 t.ha $^{-1}$ year $^{-1}$, as was eroded before afforestation works.

\section{References}

Chang, M 2006, Forest Hydrology - An Introduction to Water and Forest, second edition, CRC Press, Boca Raton, Florida, U.S.A.

Clinciu, I 2008, 'Prof. Stelian Munteanu's scientific visions and forecasts, in the context of the new European concepts and programs in the field of river basin management', Silvologie, vol VI, Arranging of torrential basins, Romanian Academy Publishing House, Bucharest, pp. 43-114. In Romanian.

Constandache, C \& Nistor, S 2008, Ecological reconstruction of the ravishing and sliding lands in the area of the Sub Carpathian and the Moldavian Plateau, II Series, Silvica Publishing House, Bucharest. In Romanian. 


\section{INTERNATIONAL SYMPOSIUM "THE ENVIRONMENT AND THE INDUSTRY", SIMI 2018, PROCEEDINGS BOOK}

Constandache, C, Nistor S, Ivan, V, Munteanu, F \& Pacurar, VD, 2010, 'Functional efficiency of forestry crop protection and the improvement works of degraded lands', Forest Magazine, no.1, pp. 26-31. In Romanian.

Constandache, C, Dinca, L, Nistor, S \& Crisan, V 2016, 'Causes of land degradation in Vrancea. Forestry measures to improve degraded land ', Pedogenic Factors and Processes in the Temperate Zone, vol. 1, no 15, pp. 57-68. In Romanian.

Constandache, C, Peticila, A, Dinca, L \& Vasile, D 2016, 'The usage of Sea Buckthorn (Hippophae Rhamnoides L.) for improving Romania's degraded lands', Agro Life Scientific Journal, vol. 5, no. 2, pp. 50-58.

Costin, A 2006, 'Forest, the most important factor in maintaining hydrological balance', in Silvologie, vol. V, Forest and water regime, Romanian Academy Publishing House, Bucharest. In Romanian.

Dinca, L, Dinulica, F, Socaciu, C, Constandache, C, Blaga, T \& Peticila, A 2018, 'Hipphophae Salicifolia D. Don - a miraculous species less known in Europe', Notulae Botanicae Horti Agrobotanici Cluj-Napoca, vol. 46, no. 2, pp. 474483.

Giurgiu, V 2010, 'Considerations on Romania's forests, Part I. Decline in forests and marginalization of forests', Forest Magazine, no.2, pp. 3-16. In Romanian.

Popov, E, Hinkov, G, Kachova, V, Constandache, C \& Dinca, L 2017, 'A brief review of forest shelter belt establishments in Bulgaria and Romania', Revista de Silvicultura si Cinegetica, no. 41, pp. 16-23.

Silvestru-Grigore, CV, Dinulica, F, Sparchez, G, Halalisan, AF, Dinca, L, Enescu, R \& Crisan, V 2018, 'The radial growth behaviour of pines (Pinus sylvestris L. and Pinus nigra Arn.) on Romanian degraded lands', Forests, vol.9, no.4, pp. 213.

Traci, C \& Untaru, E 1986, The ameliorative and consolidation behaviour and effect for forest cultures from degraded lands from experimental perimeters, ICAS, II Series, Bucharest.

Untaru, E, 2000, 'Results of scientific research on forest resettlement in torrential river basins', Symposium River basin arrangement, Romanian Academy, pp. 37-43. In Romanian.

Untaru, E, Constandache, C \& Nistor, S 2006, Forestation degraded lands and preventing floods, in Silvologie, vol. V, Forest and water regime, Romanian Academy Publishing House, Bucharest, pp. 232-244. In Romanian.

Untaru E, Constandache C \& Nistor S 2013, 'The current state and future projections for the ecological reconstruction through the afforestation of degraded lands from Romania (II)', Forest Magazine, no.1, pp. 16-26. 